\title{
Safety Assessment Analysis for Legacy Radioactive Waste
}

\author{
Arkan T. AL-Qaraghuli ${ }^{1}$, Zaki A. Mansoor ${ }^{2}$, Ali K. Kadhim ${ }^{3}$ \\ ${ }^{1}$ Radioactive Waste Treatment \& Management Directorate (RWTMD), MOST, Baghdad, Iraq \\ ${ }^{2}$ Radiation Protection Department, MOST, Baghdad, Iraq \\ ${ }^{3}$ Nuclear Safety Department, MOST, Baghdad, Iraq
}

Email address:

arkanturki@yahoo.com (A. T. AL-Qaraghuli)

\section{To cite this article:}

Arkan T. AL-Qaraghuli, Zaki A. Mansoor, Ali K. Kadhim. Safety Assessment Analysis for Legacy Radioactive Waste. International Journal of High Energy Physics. Vol. 4, No. 6, 2017, pp. 99-103. doi: 10.11648/j.ijhep.20170406.15

Received: October 2, 2017; Accepted: October 24, 2017; Published: December 27, 2017

\begin{abstract}
The storage facility is located at AL-Tuwaitha nuclear research site; it is intended for temporary storage of the radioactive waste (RW) with low half-life and low or medium radioactivity. The annual doses are calculated for the workers and public of the storage facility from a hypothetical accident involving drums falls to the ground by different climatic conditions. The results show the safety and exposure of the workers normal operational and public in accident scenario during periods to legacy RW drums in storage facility. In this study the results by SAFRAN calculations (SAFRAN is a computer program used to assess the safety of workers in the radiation fields and the main objective of using the program is to know the activities and activities that include high radiation dose affecting the workers and the public and the development of treatments for the purpose Reduced radiation dose) in Table (4) for normal operation showed that the highest radiation dose of the two most active radiation measurements and the sorting of drums was up to $430 \mu \mathrm{Sv}$, which is acceptable for radiation field workers where $(2.5 \%)$ of the annual value set by International Commission on Radiological Protection (ICPR) for radiation workers, which amounts to $20 \mathrm{mSv}$ per year. The results of the scenario of the possible accidents occurred. The highest possible dose to be received by the workers in Table (5) is $5.68 \mu \mathrm{Sv}$ in the treatment of the extreme rain incident, which may enter the storage facility due to a fault in the discharge of water. Within the limits of the dose of accidents assumed by the SAFRAN program as an accident dose is the same as the one allowed by the ICPR which is $1 \mathrm{mSv}$ per year, where $5.68 \mu \mathrm{Sv}$ is equivalent to $0.5 \%$ of the permissible dose.
\end{abstract}

Keywords: Safety Assessment, Waste Management, Dose Rate

\section{Introduction}

Safety assessment, an integral and important part of the safety case, is driven by a systematic assessment of radiation hazards. The latter involves quantification of radiation dose and radiation risks that may arise from the facility or activity for comparison with dose and risk criteria, and provides an understanding of the behavior of the facility or activity under normal conditions and anticipated operational occurrences and in the event of accidents [1, 2, 3-4].

Waste management facilities and activities are varied in nature, size and complexity, and have different hazards associated with them, both from normal operation and from accidents. The magnitude and content of the radioactive inventory is also varied. Furthermore, a waste management facility or activity could be one of several facilities or activities on a site and may be independent of the other facilities, may be connected to other facilities or may be an integral part of a larger facility. Commensurately, the extent and complexity of the safety case and supporting safety assessment will differ according to the facility or activity, and will evolve through its lifetime (e.g. construction, commissioning, and operation). In view of these considerations, a graded approach is required to be applied to the development and review of the safety case and supporting safety assessment [4, 5, 6-7].

The RW in Iraq comes from two major origins, the first one is the legacy waste which in turns comes from unidentified treated RW from contaminated wreckages and debris resulted from the second Gulf War in 1991, the second is the waste expected from the decommissioning of the destroyed nuclear buildings and facilities. Additionally, there 
are moderate quantities radioactive waste that comes from other activities in the universities, researches, agriculture and medical applications [2, 5, 8-9].

\section{Objective}

The objective of this assessment is to evaluate the consequences of radiological hazards in the waste management activities during normal storage operations period and during the occurrence of accidents for the workers and the public (for the nearest residential area from the store).

\section{Storage Facility}

The storage facility (as a part of radioactive waste management and treatment directorate (RWTMD) tasks) is located in Al-Tuwaitha nuclear research site, Baghdad. The storage facility established for temporary storage purposes of the radioactive waste containers and drums (shown in figure 1) [8-9]. There are 430 drums of radioactive legacy waste stored in the storage facility for low half-life radioactive waste.

The storage facility was designed with (70 m length, $20 \mathrm{~m}$ width and $9 \mathrm{~m}$ height) and a floor of concrete, also has two gates with a width of $(4.5 \mathrm{~m})$, the storage facility is designed according to the following specifications:

a. Storage capacity (2000 drums), including concrete containers.

b. The temperature inside the storage facility should not exceed $\left(60^{\circ} \mathrm{C}\right)$.

c. The height is $(9 \mathrm{~m})$ to ensure get air flow rate is about $\left(14000 \mathrm{~m}^{3} / \mathrm{h}\right)$.

d. Convection currents are used to dispose of gases which produced as a result of decay of stored elements.

e. The gate allows passage of a vehicle to transport the drums and containers.

f. The thickness of the sandwich panel walls is $0.05 \mathrm{~m}$.

g. The storage facility has two cranes at height of $8 \mathrm{~m}$ and a load of (10 tons).

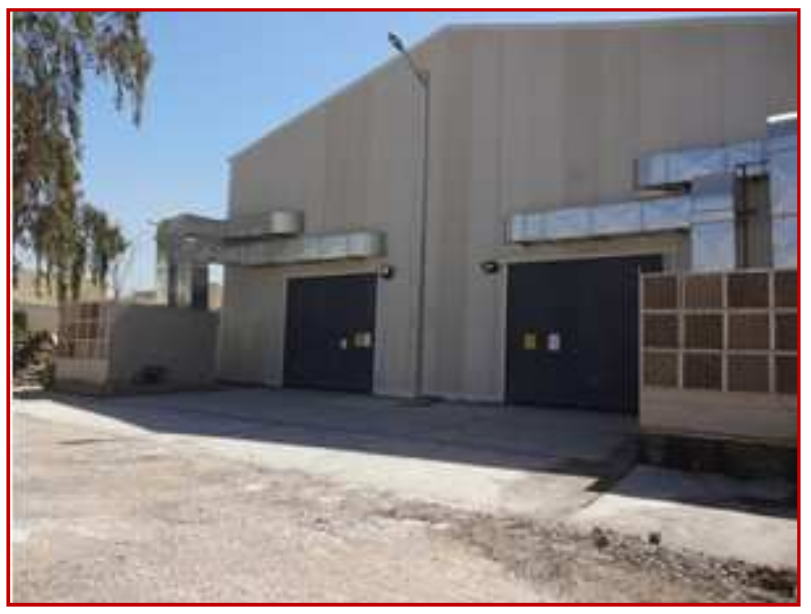

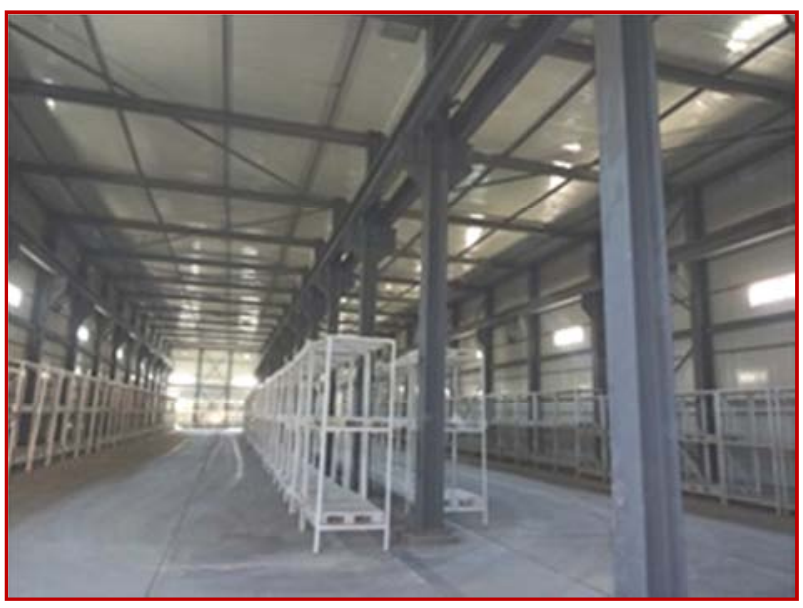

Figure 1. The storage facility at AL-Tuwaitha research nuclear site.

\section{Materials \& Method}

\subsection{Equipment \& Materials}

\subsubsection{Hand Held High Purity Germanium (HX)}

Germanium portable device for the determination of isotopes and spectroscopy for Gama spectra, and its specification:

Internal HPGe (is already acknowledged as the "perfect" detector for a radioisotope identifier) detector P-type highpurity germanium. Coaxial construction, crystal nominal dimensions $50 \mathrm{~mm}$ diameter $\mathrm{x} 30 \mathrm{~mm}$ length.

Gamma dose rate detector two detectors determine the gamma dose rate over a wide range from $<0.05 \mu \mathrm{Sv} / \mathrm{h}$ to $>10000 \mu \mathrm{Sv} / \mathrm{h}$.

Internal Neutron Detector Module Single He tube: 4 "active lengths, 0.5 " diameter, $20 \mathrm{~atm} \mathrm{He} 3$ fill pressure. High density polyethylene moderator. 5.5 in $\times 1.3$ in $x 1.3$ in. approximately.

GPS internal NMEA compliant WAAS capable.

Temperature operation Range: $-10^{\circ} \mathrm{C}$ to $40^{\circ} \mathrm{C}$ [10].

\subsubsection{LUDLUM Model 2241-2}

The model $2241-2$ is a portable microprocessor-based digital scaler/ratemeter designed for use with scintillation, Geiger-Mueller (G-M), and proportional type detectors to measure ionizing radiation. Programmable display units are represented in either $\mathrm{R} / \mathrm{hr}, \mathrm{Sv} / \mathrm{h}$, cpm or cps with multipliers of micro $(\mu)$ or milli $(\mathrm{m})$ for $\mathrm{R} / \mathrm{hr}$ and $\mathrm{Sv} / \mathrm{h}$ and kilo $(\mathrm{k})$ for cpm or cps. The temperature range: $-20^{\circ} \mathrm{C}$ to $-50^{\circ} \mathrm{C}[11]$.

\subsection{Experimental Method}

The drum is isolated and then the radiation dose of the drum is measured contact with it and the radiation dose of the drum is measured at a distance of $1 \mathrm{~m}$ also to obtain the radiation dose received by the workers during the performance of various radiological activities, After that the radiation doses of all drums (430 drum) were documented and tabulated in the form of specific classes within multiple levels to obtain a higher average radiation dose that Reached $20 \mu \mathrm{Sv} / \mathrm{h}$ as a contact dose with the drum. 
Hand held high purity Germanium HX was used to obtain radionuclide concentrations inside the drums and the activity of the radioactive radionuclides was determined also.

After determining the radiation dose the time required for each activity, all data is entered into the SAFRAN program, also introducing special scenarios for the expected occurrence incidents during the implementation of activities. The calculations are calculated by SAFRAN and get the received dose for workers during the implementation of activity and the dose received for workers and the public during radiological accidents also (The public in this activity is facility protection service (FPS) and other on-site staff).

\section{Results}

Safety assessment accomplished using SAFRAN program during normal operation of the storage facility and during incident or probably events as input data tables and output results. Table 1 , is the inventory for 430 drums of RW, Tables $(2,3)$ represent a process in the store with their description and exposure time for each activity; and SAFRAN inputs for 430 legacy radioactive waste drums. Table (4) represent safety assessment SAFRAN output of RW legacy waste at normal operation and tables $(5,6,7,8)$ safety assessment SAFRAN output risk for accident situation and hazard factors for worker, driver and public per each activity [12].

Table 1. Inventory for 430 drums of $R W$ according dose rate categories.

\begin{tabular}{lll}
\hline No. & $\begin{array}{l}\text { Dose rate } \\
\boldsymbol{\mu S v} / \mathbf{h}\end{array}$ & $\begin{array}{l}\text { Number of } \\
\text { Drums }\end{array}$ \\
\hline 1 & $0.1-1$ & 352 \\
2 & $1-3$ & 17 \\
3 & $3-5$ & 12 \\
4 & $5-10$ & 17 \\
5 & $10-50$ & 24 \\
6 & $50-600$ & 8 \\
\hline
\end{tabular}

Table 2. Duration of exposure for each activity.

\begin{tabular}{|c|c|c|}
\hline Activity & Description & EXPOSURE TIME (h/y) \\
\hline Radiation measurement for drums. & Exposure of physicist during the Radiation measurements for drums. & $\begin{array}{l}3 \mathrm{~min} \text { for each Drum } \\
\text { (430 drum) } 21.5 \mathrm{~h} \text { total }\end{array}$ \\
\hline Sorting of drums & Exposure of operator during sorting of drums. & $\begin{array}{l}3 \text { min for each Drum } \\
\text { (430 drum) } 21.5 \mathrm{~h} \text { total }\end{array}$ \\
\hline Arrangement of drums in the storage. & Exposure of operator during the Arrangement of drums. & $\begin{array}{l}5 \text { min for each Drum } \\
\text { (430 drum) } 35.8 \mathrm{~h} \text { total }\end{array}$ \\
\hline Cleaning of store & Exposure of operator during the Cleaning the storage. & $\begin{array}{l}1 \mathrm{~h} \text { in the week } \\
\text { (50 week) } 50 \mathrm{~h} \text { total }\end{array}$ \\
\hline Inspection & Exposure of operator during the inspection the Drums in the Storage. & $\begin{array}{l}15 \mathrm{~min} \text { in the week } \\
\text { (50 week) } 12.5 \mathrm{~h} \text { total }\end{array}$ \\
\hline
\end{tabular}

Table 3. Represent SAFRAN inputs for 430 RW Legacy Waste Drum.

\begin{tabular}{|c|c|c|c|c|}
\hline parameter & Nuclide & user-defined value (prioritized) & SAFRAN suggest & unit \\
\hline Duration & & $4.00 \mathrm{E}-2$ & & Year \\
\hline Annual volume of waste & & & $2.15 \mathrm{E}+3$ & $\mathrm{~m}^{3} / \mathrm{y}$ \\
\hline Total volume of waste & & $8.60 \mathrm{E}+1$ & & $\mathrm{~m}^{3}$ \\
\hline Annual mass of waste & & & $2.15 \mathrm{E}+6$ & $\mathrm{~kg} / \mathrm{y}$ \\
\hline Total mass of waste & & $8.60 \mathrm{E}+4$ & & $\mathrm{Kg}$ \\
\hline Type of container & & drum $200 \mathrm{~L}$ & & \\
\hline Internal volume of container & & $2.00 \mathrm{E}-1$ & & $\mathrm{~m}^{3}$ \\
\hline Mass of waste in one container & & $2.00 \mathrm{E}+2$ & & $\mathrm{Kg}$ \\
\hline Annual number of waste components & & & $1.08 \mathrm{E}+4$ & per year \\
\hline Total number of waste components & & & $4.30 \mathrm{E}+2$ & \\
\hline Volumetric concentration & Cs-137 & & $1.74 \mathrm{E}+8$ & $\mathrm{~Bq} / \mathrm{m}^{3}$ \\
\hline Mass concentration & Cs-137 & $1.74 \mathrm{E}+5$ & & $\mathrm{~Bq} / \mathrm{kg}$ \\
\hline Activity of one waste component & Cs-137 & & $3.48 \mathrm{E}+7$ & $\mathrm{~Bq}$ \\
\hline Total activity & Cs-137 & & $1.50 \mathrm{E}+10$ & $\mathrm{~Bq}$ \\
\hline Annual activity & Cs-137 & & $3.74 \mathrm{E}+10$ & $\mathrm{~Bq} / \mathrm{y}$ \\
\hline
\end{tabular}


Table 4. Represent Safety Assessment SAFRAN Output for Normal Operation.

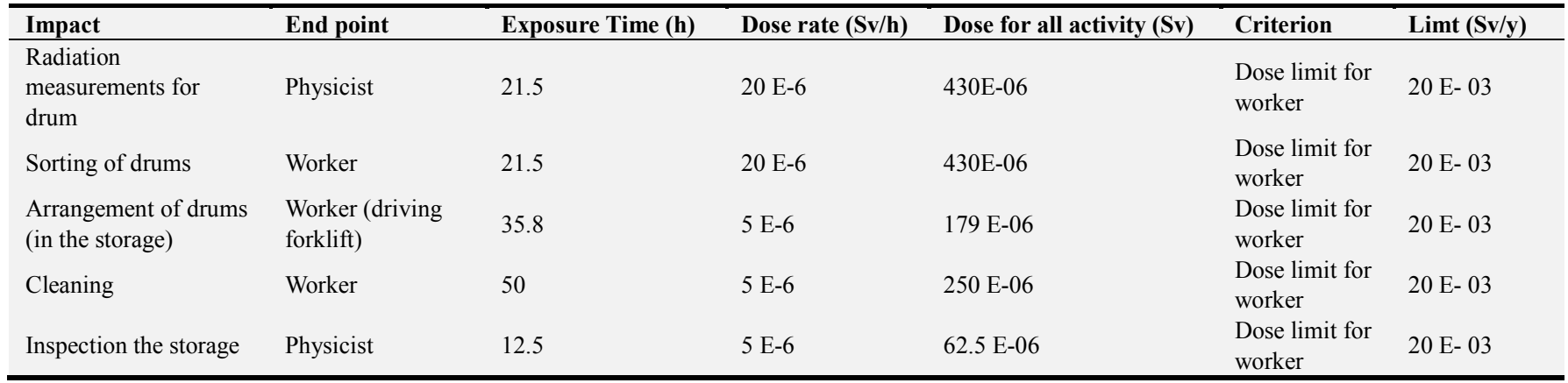

In Table (4) for normal operation showed that the highest radiation dose of the two most active radiation measurements and the sorting of drums was up to $430 \mu \mathrm{Sv}$, which is acceptable for radiation field workers where $(2.5 \%)$ of the annual value set by International Commission on Radiological Protection (ICPR) for radiation workers, which amounts to $20 \mathrm{mSv}$ per year.

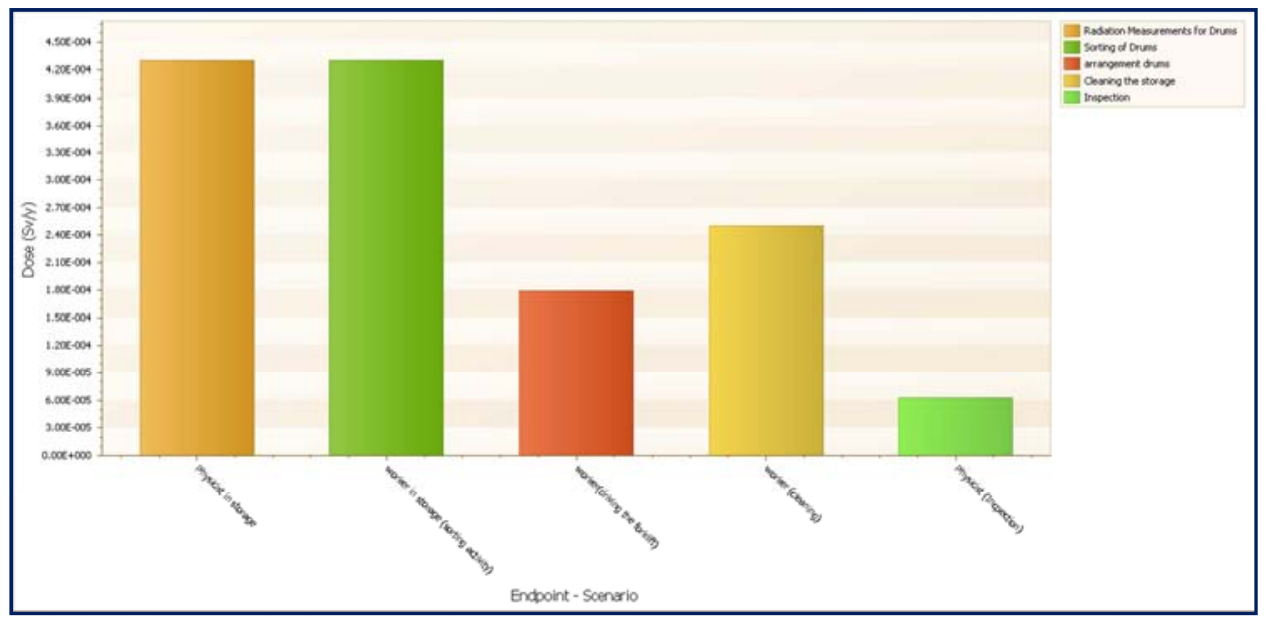

Figure 2. Showing the Risk Comparison as well as the Annual Dose of Each Factor within each Process.

Table 5. Comparison of Doses inside the store for Accident Scenario.

\begin{tabular}{|c|c|c|c|c|c|c|}
\hline Scenario & Impact & $\begin{array}{l}\text { Probability - } \\
\text { qualitative }\end{array}$ & End point & Dose (Sv) & Criterion & Limit (Sv) \\
\hline $\begin{array}{l}\text { Delay action in the storage } \\
\text { (failure forklift ) }\end{array}$ & $\begin{array}{l}\text { Impact for scenario Delay } \\
\text { action in the storage }\end{array}$ & Low & Physicist in storage room & $3.69 \mathrm{E}-8$ & $\begin{array}{l}\text { Dose limit for } \\
\text { worker }\end{array}$ & $1.00 \mathrm{E}-3$ \\
\hline $\begin{array}{l}\text { Delay action in the storage } \\
\text { (failure forklift ) }\end{array}$ & $\begin{array}{l}\text { Impact for scenario Delay } \\
\text { action in the storage }\end{array}$ & Low & worker (sorting drums) & $3.69 \mathrm{E}-8$ & $\begin{array}{l}\text { Dose limit for } \\
\text { worker }\end{array}$ & $1.00 \mathrm{E}-3$ \\
\hline $\begin{array}{l}\text { Delay action in the storage } \\
\text { (failure forklift ) }\end{array}$ & $\begin{array}{l}\text { Impact for scenario Delay } \\
\text { action in the storage }\end{array}$ & Low & worker(driver of forklift) & $2.35 \mathrm{E}-8$ & $\begin{array}{l}\text { Dose limit for } \\
\text { worker }\end{array}$ & $1.00 \mathrm{E}-3$ \\
\hline Dropping waste drum & $\begin{array}{l}\text { Impact for scenario Dropping } \\
\text { waste drum }\end{array}$ & Medium & Physicist in storage room & $3.69 \mathrm{E}-8$ & $\begin{array}{l}\text { Dose limit for } \\
\text { worker }\end{array}$ & $1.00 \mathrm{E}-3$ \\
\hline Dropping waste drum & $\begin{array}{l}\text { Impact for scenario Dropping } \\
\text { waste drum }\end{array}$ & Medium & worker (sorting drums) & $3.69 \mathrm{E}-8$ & $\begin{array}{l}\text { Dose limit for } \\
\text { worker }\end{array}$ & $1.00 \mathrm{E}-3$ \\
\hline Dropping waste drum & $\begin{array}{l}\text { Impact for scenario Dropping } \\
\text { waste drum }\end{array}$ & Medium & worker(driver of forklift) & $2.35 \mathrm{E}-8$ & $\begin{array}{l}\text { Dose limit for } \\
\text { worker }\end{array}$ & $1.00 \mathrm{E}-3$ \\
\hline Fire in the storage facility & $\begin{array}{l}\text { Impact for scenario Fire in } \\
\text { the storage facility }\end{array}$ & Low & worker in fire Accident & $2.94 \mathrm{E}-9$ & $\begin{array}{l}\text { Dose limit for } \\
\text { worker }\end{array}$ & $1.00 \mathrm{E}-3$ \\
\hline Extreme rain & $\begin{array}{l}\text { Impact for scenario Extreme } \\
\text { rain }\end{array}$ & Low & Physicist in storage room & $5.68 \mathrm{E}-6$ & $\begin{array}{l}\text { Dose limit for } \\
\text { worker }\end{array}$ & $1.00 \mathrm{E}-3$ \\
\hline Strong wind & $\begin{array}{l}\text { Impact for scenario Strong } \\
\text { wind }\end{array}$ & Low & worker (sorting drums) & $3.69 \mathrm{E}-7$ & $\begin{array}{l}\text { Dose limit for } \\
\text { worker }\end{array}$ & $1.00 \mathrm{E}-3$ \\
\hline
\end{tabular}

The results of the scenario of the possible accidents occurred. The highest possible dose to be received by the workers in Table (5) is $5.68 \mu \mathrm{Sv}$ in the treatment of the extreme rain incident, which may enter the storage facility due to a fault in the discharge of water. Within the limits of the dose of accidents assumed by the SAFRAN program as an accident dose is the same as the one allowed by the ICPR which is $1 \mathrm{mSv}$ per year, where $5.68 \mu \mathrm{Sv}$ is equivalent to 
$0.5 \%$ of the permissible dose. The approved annual dose for

the public $(1 \mathrm{mSv} / \mathrm{y})$.

workers during accidents is the same as the dose limits for

Table 6. Comparison of Doses Outside the store for Fire Scenario.

\begin{tabular}{lllllll}
\hline Scenario & Impact & Probability- qualitative & Endpoint & Dose (Sv) & Criterion & Limit (Sv) \\
\hline $\begin{array}{l}\text { Fire in the storage } \\
\text { facility }\end{array}$ & $\begin{array}{l}\text { Impact for scenario Fire } \\
\text { in the storage facility }\end{array}$ & Low & $\begin{array}{l}\text { public in fire } \\
\text { accident }\end{array}$ & $4.24 \mathrm{E}-8$ & $\begin{array}{l}\text { Dose limit for } \\
\text { public }\end{array}$ & $1.00 \mathrm{E}-003$ \\
\hline
\end{tabular}

Table 7. Comparison of Hazards Inside the store for Accident Scenario.

\begin{tabular}{|c|c|c|c|c|}
\hline Scenario & Impact & $\begin{array}{l}\text { Probability - } \\
\text { qualitative }\end{array}$ & $\begin{array}{l}\text { Impact - } \\
\text { quantitative }\end{array}$ & $\begin{array}{l}\text { Impact - } \\
\text { qualitative }\end{array}$ \\
\hline Delay action in the storage & Impact for scenario Delay action in the storage & Low & $1.42 \mathrm{E}-1$ & Low \\
\hline Fire in the storage facility & Impact for scenario Fire in the storage facility & Low & $7.10 \mathrm{E}-1$ & Low \\
\hline Extreme rain & Impact for scenario Extreme rain & Low & $1.53 \mathrm{E}+000$ & Medium \\
\hline
\end{tabular}

Table 8. Comparison of Hazards Outside the store for Fire Scenario.

\begin{tabular}{lllll}
\hline Scenario & Impact & Probability- qualitative & Impact - quantitative & Impact - qualitative \\
\hline Fire in the storage facility & $\begin{array}{l}\text { Impact for scenario Fire in the storage } \\
\text { facility }\end{array}$ & Low & $1.06 \mathrm{E}+001$ & High \\
\hline
\end{tabular}

\section{Conclusion}

The assessment of the radiological consequences of normal and incidents that may occur in the storage are summarized in table $(4,5,6,7,8)$, shows acceptable exposure rate per activity to the storage workers. It is unanticipated that management of radioactive waste arising from normal operation will present significant nuclear or radiological emergency scenarios. In case of the most conservative normal operation, the potential dose of a worker due to sorting drums or radiation measurement will be 430 $\mu \mathrm{Sv}$ which considerably less than the occupational dose limit of $20 \mathrm{mSv} / \mathrm{y}$, assuming the unlikely case that the foreseen personal protective equipment will provide no safety function [5, 6-13], The dose consequence of an uncontrolled release is expected to be low in view of the limited radiological inventory associated with Al-Tuwitha nuclear research site [13, 14-15].

The results show compliance with the safety requirements in the radioactive waste storage site.

\section{References}

[1] INTERNATIONAL ATOMIC ENERGY AGENCY (IAEA), Predisposal Management of Radioactive Waste, IAEA Safety Standards Series No. GSR Part 5, IAEA, Vienna (2009).

[2] INTERNATIONAL ATOMIC ENERGY AGENCY, Safety Series No. 115, international basic safety standards for protection against ionizing radiation and for the safety of radiation sources, IAEA, Vienna (1996).

[3] INTERNATIONAL ATOMIC ENERGY AGENCY, Safety Report Series No. 19, Generic models for use in assessing the impact of discharges radioactive substances to the environment, IAEA, Vienna (2001).

[4] INTERNATIONAL ATOMIC ENERGY AGENCY (IAEA), Radiation Protection and Safety of Radiation Sources International Basic Safety Standard GSR part 3, Vienna, 2014.

[5] INTERNATIONAL ATOMIC ENERGY AGENCY (IAEA), "Storage of Radioactive Waste", Safety Standard No. WS-G6.1, Vienna, 2006.

[6] INTERNATIONAL ATOMIC ENERGY AGENCY (IAEA), Environmental Monitoring for Purposes of Radiation Protection "Safety Standards N0. RS-G-1.8, Vienna (2005).

[7] INTERNATIONAL ATOMIC ENERGY AGENCY, Safety Series No. 111-F, The Principles of Radioactive Waste Management, IAEA, Vienna (1995).

[8] http://www-ns.iaea.org/projects/iraq/tuwaitha.asp?s=8\&l=66.

[9] http://www-ns.iaea.org/projects/iraq/sitesoverview.asp? $\mathrm{s}=8 \& \mathrm{l}=66$.

[10] AMETEC ORTEC, Manual of Hand held high purity germanium (HX).

[11] LUDLUM MEASUREMENTS, INC, Manual of LUDLUM MODEL 2241-2 Survey Meter.

[12] SAFRAN 2 Tutorials, 2015.

[13] International Atomic Energy Agency (IAEA),"Safety Assessment for Facilities and Activities", No. GSR Part 4, Vienna, 2016.

[14] International Atomic Energy Agency (IAEA), Programmes and Systems for Source and Environmental Radiation Monitoring, IAEA safety report series No. 64, Vienna, 2010.

[15] International Atomic Energy Agency (IAEA), International Basic safety Standard for protecting people and Environment Preparedness and Response for Nuclear or Radiological Emergency, General Safety Requirements GSR part 7, 2015. 